\title{
Legal Basis of Cooperation between Ukraine and the European Union in the Space Sector
}

\author{
Julia Utko-Maslianyk \\ Ph.D. in Law, Assistant Department of European Law, \\ Lviv National Ivan Franko University (Lviv, Ukraine) \\ E-mail: utko@bigmir.net \\ https://orcid.org/ 0000-0003-1900-5082
}

The author investigates the modern legal basis of cooperation between Ukraine and the EU in the field of space. The normative and legal acts that define and provide the legal grounds for Ukraine's participation in the EU space programs, which constitute the basic legal form of realization of the European space policy, are analyzed.

Keywords: space law, space sector, European Space Policy, Space Law Ukraine

\section{Правові засади співробітництва між Україною та Свропейським Союзом у космічній сфері}

\author{
Утко-Масляник, Юлія Мирославівна \\ Кандидат юридичних наук, асистент кафедри європейського права \\ Львівський національний університет імені Івана Франка
}

(Львів, Україна)

У статті автор досліджує сучасну правову основу співпрачі України та ЄС у космічній сфері. Проаналізовано нормативно-правові акти, які визначають та забезпечують правові підстави участі України у космічних програмах СС, щзо становлять основну правову форму реалізації європейської космічної політики.

Ключові слова: космічне право, космічна сфера, європейська космічна політика, космічне право України

Received: July 26, 2018; accepted: August 30, 2018

Advanced Space Law, Volume 2, 2018: 96-111.

https://doi.org/10.29202/asl/2018/2/11

(C) Utko-Maslianyk, Julia, 2018 
Незалежна Україна впевнено увійшла до складу космічних держав світу завдяки сформованому за радянські часи науково-технічному та виробничому потенціалу ракетно-космічної галузі. Космічна сфера є однією з небагатьох тих сфер, де наша держава продовжує залишатися конкурентною на ринку та у розвитку співпраці якої зацікавлена не лише Україна, а й Європейський Союз (далі - СС). Статус космічної держави об'єктивно підвищує значення України у відносинах зі стратегічними партнерами, процесах інтеграції в європейські структури. Зокрема, в одному із документів, що регламентує реалізацію європейської космічної політики відзначено, що Україна заслуговує особливої уваги як країна з визнаною космічною галуззю [Commission, 2003].

Своєю чергою пріоритетність співробітництва України з СС у космічній сфері обумовлене як стратегічним, враховуючи подальше зближення України з правовою системою ЄС, так і практичним значенням, а саме у напрямку розвитку космічної промисловості та конкурентоспроможності України як космічної держави, зокрема, через участь України у європейських космічних програмах ЄС, Європейського космічного агентства (далі - СКА). Зокрема, в рамках Державного космічного агентства України (далі ДКАУ) сьогодні вивчаються умови набуття членства в СКА. Власне це сприятиме ефективному зростанню економіки нашої країни та утвердженню міжнародного іміджу України як космічної держави.

Ключовою подією у правовому регулюванні взаємовідносин між Україною та ЄС у космічній сфері стало набуття чинності 16 вересня 2014 року - Угоди про асоціацію що окреслила основні напрями розвитку двосторонньої співпраці України та ЄС у більш ніж 30 сферах, в тому числі у космічній. Космічна сфера знайшла відображення у розділі 5 «Економічне та секторальне співробітництво» глави 8 «Космос» [Угода, 2014].

Відповідно до ст. 371 цієї угоди, сторони можуть співпрацювати за такими напрямами: глобальні навігаційні супутникові системи; спостереження Землі та глобальний моніторинг; космічна наука та дослідження; прикладні космічні технології, зокрема пускові технології та технології ракетних двигунів. Окрім того, сторони заохочують і сприяють обміну досвідом щодо політики в космічній сфері, адміністрації та правових аспектів, а також щодо промислової реструктуризації та комерціалізації космічних технологій.

Угодою також передбачено, що співробітництво у цій сфері здійснюватиметься у таких правових формах: обмін інформацією щодо політики і програм сторін та відповідних можливостей для співробітництва і спільних проектів, зокрема участь українських підприємств та організацій у відповідних космічних і транспортних напрямах Рамкової програми СС з досліджень та інновацій «Горизонт 2020»; обмін науковцями та створення відповідних мереж. Співробітництво також може охоплювати обмін досвідом у сфері управління космічними дослідженнями та науковими установами, а також створення умов, сприятливих для проведення досліджень і впровадження нових технологій, захисту прав інтелектуальної, промислової та комерційної власності.

Угодою про асоціацію між Україною та ЄС передбачена можливість для України брати участь у роботі агентств СС. Відповідно до ст. 450, Україні надається можливість брати участь у роботі агентств ЄС, діяльність яких пов'язана з реалізацією цієї Угоди, а також інших агентств ЄС, якщо установчі документи це дозволяють, відповідно до умов цих установчих документів. Для забезпечення своєї участі у роботі кожного 3 таких агенств і визначення розміру їі фінансового внеску, Україна має укладати окремі угоди з СС. Відповідно до ст. 452 ЄС зобов'язаний інформувати Україну про створення 
нових агентств та нових програм, а також про зміни в умовах участі у програмах ЄС та агентствах.

Постійний діалог у космічній сфері відбуватиметься через координацію діяльності та співробітництво з СКА. Важливим кроком в напрямі формування співпраці України з СКА стало підписання 25 січня 2008 р. Рамкової угоди між Урядом України та СКА щодо співробітництва у використанні космічного простору в мирних цілях, що набула чинності після ратифікації Верховною Радою України 25 лютого 2009 р. [Угода, 2008].

Угода складається з преамбули та дев'яти статей. Основною метою угоди визначено «створення правових рамок для співробітництва між сторонами в космічній сфері та умов для виконання спільних проектів, що становлять спільний інтерес» [Угода, 2008]. Сторони угоди можуть співпрацювати за такими напрямами: космічні науки, програми дослідження Землі та їх застосування, телекомунікації, мікрогравітаційні дослідження, розробка та використання наземного сегмента, ракетоносії. Співпраця також поширюється на встановлення стипендій для надання можливості номінантам від кожної сторони проходити підготовку або брати участь у науковій або технічній діяльності в установах, запропонованих стороною, що встановлює стипендію; обмін експертами для участі в дослідженнях; скликання спільних конференцій та симпозіумів; спільне сприяння використанню продукції та послуг, розроблених в межах програм агентства; сприяння освітній діяльності в сфері космічних наук і технологій; надання експертної оцінки та допомоги в управлінні космічними проектами.

Як механізм виконання співробітництва, передбачено в укладанні імплементаційних угод щодо конкретної програми, яка становить спільний інтерес. Такі імплементаційні угоди можуть, зокрема, мати такі структурні елементи: опис цілей співробітництва; робочий план; ролі та зобов'язання сторін; правила та володіння правами інтелектуальної власності, умови обміну конфіденційною інформацією.

Для забезпечення контролю за виконанням угоди кожна зі сторін призначає відповідну інституцію. Від України такою інституцією призначено ДКАУ. На сьогодні створено низку двосторонніх інституцій у формі робочих груп з питань співробітництва між ДКАУ та СКА за такими напрямами, як космос і навколишнє середовище, космічна енергія, наземний сегмент, ракетоносії тощо.

3 метою забезпечення правосуб'єктності ЄКА у межах угоди українська сторона надає агентству привілеї та імунітети, передбачені Конвенцією про привілеї та імунітети спеціалізованих установ, що набула чинності для України 13 квітня 1966 р., прийнятої ГА ООН 1947 р. Сторони також на взаємній основі зобов'язуються, відповідно до законодавства кожної із сторін, забезпечувати адміністративне сприяння виконанню цієї угоди, а саме полегшувати та прискорювати процес переміщення осіб, імпорт та експорт товарів і матеріалів, що мають відношення до спільних проектів і необхідні для виконання цієї угоди. В угоді також закріплено порядок обміну науково-технічною інформацією.

У разі виникнення відповідальності кожна сторона, згідно з угодою, відповідає за будь-які втрати або шкоду, заподіяну іiі особам або майну в ході виконання робіт у межах цієї Угоди, окрім випадків навмисної шкоди або грубої недбалості з боку іншої сторони, за винятком умов передбачених в окремих імплементаційних угодах. В угоді передбачено два види врегулювання спорів: шляхом спільних консультацій або, якщо питання не вирішується шляхом консультацій і вимагає рішення, його передають, за вимогою однієї зі сторін, до арбітражного суду. 
3 метою практичної реалізації цієї угоди розпочато їі імплементацію шляхом розробки плану дій ДКАУ — СКА, який був офіційно погоджений з ЄКА ще у 2009 р. у м. Відень. Відповідно до цього документа, заплановано співпрацю за такими напрямами: космічні науки, програми дослідження Землі, мікрогравітаційні дослідження, ракетоносії, сприяння освітньої діяльності в сфері космічних наук і технологій.

У межах співпраці за напрямом «космічні науки» в Києві відбувся семінар з питань спільної участі в реалізації європейської космічної програми «Джеймс». Під час семінару німецькі експерти запропонували створити спільний українсько-європейський консорціум за підтримки космічного агентства Німеччини за тематикою «космічна погода» [Международное сотрудничество, 2010]. На семінарі в межах напряму «програми дослідження Землі» відбулося обговорення правових аспектів використання аерокосмічних даних дистанційного зондування Землі. Зокрема, фахівці космічного агентства Німеччини запропоновали допомогу з юридичного забезпечення створення нормативно-правової бази використання аерокосмічних даних дистанційного зондування Землі в Україні. Учасники семінару ознайомилися із законом з питань безпеки даних, одержуваних із супутників, який був прийнятим Німеччиною 23 листопада 2007 p.

У межах напряму «сприяння освітній діяльності в сфері космічних наук і технологій» ДКАУ порушило перед представниками департаменту міжнародного співробітництва ЄКА питання про форми і перспективи участі студентської молоді в космічних молодіжних програмах ЄКА. Станом на сьогодні від департаменту з питань освіти ЄКА надійшла пропозиція про участь українських університетів в європейській програмі європейський студентський місячний орбітальний апарат. Питання потенційного залучення українських університетів до роботи над цим проектом уже узгоджено 3 Національним центром аерокосмічної освіти молоді в Україні.

Отже, угода має передусім рамковий характер, встановлює загальні правові та організаційні основи для подальшого довгострокового співробітництва. Зокрема, сторони, бажаючи продовжити період їхньої співпраці в межах цієї Угоди, чинність якої, відповідно до п. 2 ст. 9, становить п'ять років, 14 лютого 2014 р. уклали додатковий протокол до неї, яким передбачено, що угода залишатиметься чинною протягом 10 років $з$ моменту набуття нею чинності, а саме до 24 лютого 2019 р. [Протокол, 2014]. Завдяки цій угоді закладається правова основа для прийняття сторонами спеціальних і секторальних угод з різних напрямів їх співпраці. Однак наразі співпраця між сторонами в межах окреслених напрямів відбувається у формі планування та організації зустрічей, семінарів, пропозицій.

Перспективи членства вперше обговорювалися 2009 р. на зустрічі Генерального директора ДКАУ з очільниками ЄКА Ж. Ж. Дорденом, космічного агентства ФРН Й. Д. Вернером та Національного центру космічних досліджень Франції Я. д’Ескатой. Під час зустрічі обговорювалися актуальні питання співробітництва в космічній сфері. Також було наголошено на прагненні України набути статус повноправного члена ЄКА. Ця ініціатива була позитивно сприйнята Генеральним директором ЄКА. Наступним логічним кроком має бути укладення європейської коопераційної угоди 3 ЄКА. Серед основних вимог, яким має відповідати держава, що бажає набути статус європейської кооперуючої держави ЄКА («European cooperating state»), — відповідність географічному критерію: укладення цієї угоди передбачено виключно для європейських держав. Крім того, з такою державою попередньо має бути підписана рамкова угода про співробітництво, що є правовою формою співпраці агентства з третьою державою, і 
водночас першим етапом на шляху до отримання повноправного членства. Для набуття статусу європейської кооперуючої держави СКА держава-кандидат повинна провести переговори та укласти європейську коопераційну угоду з агентством. На підставі цієї двосторонньої угоди, підписаної між кооперуючою державою та СКА, держава, за умови виконання певних умов, може брати участь у діяльності та програмах агентства. Така діяльність визначається у формі невід’ємної складової угоди - п’ятирічного плану спільних дій у космічній сфері, так званого плану роботи для європейської кооперуючої держави (Plan for European cooperating states, далі - «ПЕКС»), погодженого ЄКА та відповідною державою [Poncelet et al.,, 2004]. Угода складається з двох основних частин. У першій частині визначаються права та зобов'язання європейської кооперуючої держави, а також регламентуються питання, пов'язані і з інтелектуальною власністю, порядком та умовами обміну інформацією, привілеями та імунітетами, відповідальністю, вирішенням суперечок і набуттям чинності [European, 1975]. Друга частина — це «ПЕКС», підписаний сторонами не пізніше ніж через один рік $з$ дня підписання європейської коопераційної угоди.

Метою «ПЕКС» $є$ асоціювати державу, яка уклала європейську коопераційну угоду, до програм і діяльності ЄКА з тим, щоб у найбільш ефективний спосіб підготовити іiі до можливого майбутнього приєднання до ЄКА. Конкретні завдання плану: розвиток наукових і прикладних напрямів космічної діяльності між європейською коопераційною державою та державами — членами ЄКА; створення та зміцнення промислового потенціалу з тим, щоб забезпечити справедливу та рівноправну участь у майбутніх програмах агентства після приєднання до конвенції СКА; забезпечення доступу до програм та діяльності СКА; ознайомлення з особливостями функціонування структури СКА; забезпечення узгодженості космічної діяльності держави, яка уклала європейську коопераційну угоду, та держав - членів СКА з метою уникнення дублювання [European, 2018]. «ПЕКС» переважно охоплює такі сфери співпраці: космічну науку (астрономія, астрофізика, дослідження сонячної системи); наземне спостереження (моніторинг навколишнього середовища, метеорологія, аерономія, геодезія); зв'язок та навігація; життя та фізичні науки (космічна біологія та медицина); створення наземного сегмента та його використання. До переваг статусу держави, яка уклала коопераційну угоду, належить право використовувати активи та космічну інфраструктуру агентства та його держав-членів для реалізації власних національних космічних проектів. Зареєстровані фірми європейської кооперуючої держави береть участь у тендерній системі СКА. Держава має також право використовувати європейську космічну інфраструктуру, а також послуги, що надаються космічними системами агентства та його держав-членів при плануванні та реалізацій своїх національних космічних програм на умовах, що застосовуються до держав-членів агентства. Крім того, європейська кооперуюча держава повинна надавати підтримку СКА в сприянні використанню такої інфраструктури міжнародними організаціями, членом яких вона є. Це положення не лише посилює роль ЄКА, а й розширює іiі промисловий потенціал та надає можливість залучати додаткові інвестиції. Ще однією вагомою перевагою статусу європейської кооперуючої держави є застосування до неї особливого фінансового механізму під назвою «принцип справедливого географічного повернення». Суть цього принципу полягає у тому, що вкладені у діяльність СКА кошти повертаються до держави у формі замовлень, які ЄКА на підставі контрактів доручає виконувати підприємствам відповідної держави [Contracting for Space, 2011]. 
Мінімальний фінансовий внесок до бюджету СКА складає 1 млн євро на рік для держави, яка підписала європейську кооперуючу угоду. Окрім того, нова угода передбачає право європейської кооперуючої держави брати участь у програмах ЄКА, приєднавшись до «ПЕКС», при цьому фактично не стаючи учасником програм ЄКА, як це передбачено п. 2 ст. 14 Конвенції СКА [Конвенція, 2002]. Строк дії угоди становить п’ять років з моменту набуття чинності. Після завершення цього строку, залежно від досягнутих результатів, передбачені три варіанти співпраці держави, що уклала європейську коопераційну угоду з СКА:

1. Свропейська кооперуюча держава може пролонгувати угоду ще на п’ять років.

2. Держава має право подати заявку на асоційоване членство.

3. Держава може безпосередньо подати заявку на набуття повноправного членства y СКА.

Отже, уклавши таку угоду, держава отримує низку переваг: чіткий план реалізації сфер космічного співробітництва, погоджений спільно ЄКА та відповідною державою; право європейської кооперуючої держави використовувати активи та космічну інфраструктуру агентства та його держав-членів для реалізації національних космічних проектів; ця угода наблизить на крок нашу державу до вступу у цю міжнародну організацію, оскільки успішне виконання цієї угоди протягом п'яти років передбачає право європейської держави на подання заявки для вступу в цю організацію; фінансовий механізм, що застосовуються у цій угоді, сприятиме розвитку національної космічної промисловості, оскільки інвестиції, згідно з принципом геоповернення, повернуться у формі контрактів і замовлень, які українська космічна промисловість і науково-дослідні інститути зможуть отримати від ЄКА. Основою та важливою передумовою для укладення нової поглибленої угоди про співробітництво з Свропейським космічним агентством послужить Рамкова угода між Урядом України та СКА про співробітництво у використанні космічного простору в мирних цілях, яка залишатиметься чинною до 24 лютого 2019 p.

Крім того, Україна, маючи значний технологічний потенціал у космічній сфері, може отримувати значну користь від участі космічних програмах ЄС. Роль і значення європейської космічної політики СС характеризується новими завданнями у вирішенні проблем безпеки, економічного та науково-технічного зростання, глобальних проблем людства. Одними із інструментів реалізації поставлених завдань у сфері європейської космічної політики виступають європейські космічні програми, які, відповідно до статті 189 Лісабонського договору, є основною правовою формою реалізації європейської космічної політики [Treaty of Lisbon, 2007]. Питання участі та доступу України до програм ЄС регламентовані розділом 5 «Економічне та галузеве співробітництво» Угоди про асоціацію, зокрема у главі 28 (ст. 451) «Участь у програмах та агентствах СС», а також у додатку до угоди, а саме в Протоколі 3 «Про Рамкову угоду між Україною та ЄС про загальні принципи участі України в програмах ЄС».

Цими правовими актами встановлено так званий рамковий правовий механізм участі України у програмах ЄС. Зокрема, безпосередньо правові підстави участі України у програмах ЄС визначені у ст. 451 Угоди про асоціацію: «Україні надається можливість брати участь у всіх поточних і майбутніх програмах Союзу, відкритих для України згідно з відповідними положеннями, якими запроваджуються ці програми». Участь України у конкретній програмі ЄС є предметом Меморандуму про взаєморозуміння з Європей- 
ською Комісією. Зокрема, у ст. 5 Протоколу 3 «Про Рамкову угоду між Україною та ЄC про загальні принципи участі України в програмах ЄС» зазначено, що «конкретні терміни та умови участі України у кожній окремій програмі, зокрема сплачуваний фінансовий внесок і процедури звітування та оцінки, визначатимуться в Меморандумі про взаєморозуміння між Комісією та компетентними органами України на базі критеріїв, встановлених цими програмами» [Протокол, 2011]. Протокол послужив правовою основою для укладення двосторонніх угод про доступ України до програм СС, у тому числі космічних.

Серед нормативно-правових актів Свропейського Союзу, що регламентують умови участі у тематичних програмах $\mathrm{CC}$, у тому числі і космічних слід відзначити регламент Ради ЄС про створення Рамкової програми Горизонт 20203 досліджень та інновацій (2014-2020) [Регламент, 2013]. Остання є важливим інструментом реалізації як науково-технологічної, так і європейської космічної політики. Механізми цієї програми передбачають широкі можливості для міжнародної співпраці, зокрема, можливість для третіх країн брати участь у конкурсах програми з метою отримання фінансування для реалізації спільних науково-дослідних проектів за всіма тематичними розділами і напрямами, у тому числі і космічної [Чернишев et al., 2012].

Співробітництво у космічній сфері складає суттєву частину у 8 Рамковій програмі «Горизонт 2020». Пріоритетними програмами співробітництва у цій сфері визначено: глобальні навігаційні супутникові системи, а саме створення європейської глобальної системи супутникової навігації «Галілео», основне призначення якої полягає у наданні навігаційних послуг; створення європейської глобальної системи спостереження за планетою Земля. Основне призначення цієї програми передбачає створення супутникових систем і пов'язаних з ними наземної інфраструктури в Європі для спостереження за поверхнею Землі та забезпечення геоінформаційних послуг, які дають доступ до точних даних і інформації у сфері навколишнього середовища та безпеки для громадян Свропи та інших країн; прикладні космічні технології, зокрема пускові технології та технології ракетних двигунів.

У цьому зв’язку, слід відзначити, що Угодою про асоціацію між Україною та ЄС передбачено можливість для співробітництва та спільних програм у космічній сфері, зокрема через участь українських підприємств та організацій у відповідних космічних напрямах восьмої Рамкової програми Свропейського Союзу з досліджень та інновацій «Горизонт 2020». Однак, набуття чинності угоди про асоціацію для України не означає про автоматичне отримання нею асоційованого статусу у цій програмі. Для набуття такого статусу необхідним є укладення спеціального двостороннього документу про асоціацію України до Рамкової програми з наукових досліджень та технологічного розвитку.

Важливим етапом розвитку правових засад співпраці з Свропейським Союзом у космічній сфері стало підписання Угоди між Україною та Європейським Союзом про асоційовану участь України в програмі СС «Горизонт 2020», яка набула чинності 17 серпня 2015 р [Угода, 2015]. Значення цієї угоди для нашої держави полягає у тому, що, по-перше, вона як асоційована країна братиме участь у всіх заходах і тематичних пріоритетах, у всіх програмних комітетах Рамкової програми СС, іiї дослідницькі установи фінансуватимуться за рахунок підтримки Європейської Комісії на однакових умовах 3 установами держав - членів СС, по-друге, правовий механізм участі України у цій програмі визначається правовими актами ЄС, що застосовуються до держав - членів ЄС. 
А саме, участь України у заходах Рамкової програми «Горизонт 2020» регламентується угодою між Україною та Європейською Комісією про асоційовану участь України в програмі ЄС «Горизонт 2020», додатками до неї, а також правовими актами, визначеними у ст. 1 цієї угоди, зокрема: регламенту № 1291/2013 про створення Рамкової програми «Горизонт 2020» 3 досліджень та інновацій (2014-2020) [Регламент, 2013]; регламенту Європейського Парламенту та Ради № 1290/2013 від 11 грудня 2013 р., що встановлює правила участі у програмі «Горизонт 2020» [Регламент, 2013], включаючи делеговані акти та будь-які інші подальші правила; Рішення Ради № 743/2013 про створення спеціальної програми 3 реалізації «Горизонт 2020» та інших правил, що стосуються реалізації програми «Горизонт 2020» [Регламент, 2013: 965]. Регламент Європейського Парламенту та Ради № 294/2008/СС зі змінами, внесеними Регламентом Європейського Парламенту та Ради № 1292/2013 про заснування Свропейського інституту інновацій та технологій, застосовується до участі українських організацій в освітніх та інноваційних товариствах [Регламент, 2013: 174-184].

3 набуттям асоційованого статусу у Рамковій програмі Україна отримала: можливість пропонувати тематику конкурсів, на які приймаються грантові заявки, брати участь у роботі дорадчих груп і програмних комітетів Свропейської Комісії, більше можливостей для пошуку закордонних партнерів. Наприклад, щоб подати заявку на конкурс Рамкової програми необхідно сформувати консорціум щонайменше 3 трьох юридичних осіб 3 різних країн. Тепер українські учені, університети, науково-дослідні інститути зможуть входити до консорціумів як одна з обов'язкових, а не додаткових сторін. Умови участі юридичних осіб України в програмі визначені у додатку 1 Угоди про асоційовану участь України в програмі СС «Горизонт 2020».

Серед умов приєднання України до програми, важливе місце посідають фінансування. Відповідно до ст. 2 угоди, Україна повинна сплачувати фінансовий внесок до бюджету СС кожного року участі у програмі. Ці кошти йдуть на забезпечення реалізації, управління та функціонування програми. За зверненням України частина іiі фінансового внеску може забезпечуватися за рахунок відповідного зовнішнього інструменту допомоги ЄС, умови якої попередньо мають бути визначені у відповідних фінансових угодах. Правила, що регулюють фінансові внески України, викладені у Додатку 2 до угоди. Враховуючи складну фінансову ситуацію в Україні, СС як сторона угоди запропонував 95-відсоткову знижку на фінансовий внесок (який також можна додатково зменшити на 50\% за рахунок фондів інструменту європейського сусідства і партнерства [Про ратифікацію, 2015].

Ефективній реалізації угоди покликане сприяти положення про контроль та оцінювання. Відповідно до ст. 4, участь України в програмі перебуватиме під постійним спільним контролем України та Європейської Комісії на партнерських засадах. У додатку 3 до угоди визначені правила фінансового контролю відшкодувань та інші заходи протидії шахрайству. Зокрема, фінансовий контроль за діяльністю українських учасників програми здійснюватиметься через такі механізми, як прямий зв'язок, аудит, перевірки Європейської Комісії на місцях, інформування та консультування. Європейська Комісія може також застосовувати адміністративні заходи та санкції, без шкоди для застосування українського кримінального права, відповідно до регламентів № 966/2012, (СС) № 1268/2012 і № 2988/95 [Регламент, 1995].

Рішення, ухвалені Комісією в межах програми, що накладають фінансові зобов'язання на суб'єкти інші, ніж держави, підлягають виконанню в Україні. Виконання цих рішень від імені Європейської Комісії, згідно з процедурою, забезпечує орган, визначений 
Україною. У цьому випадку рішення Європейської Комісії передається українському суду без будь-яких інших процедур, окрім перевірки автентичності рішення, визначеним для цієї мети Україною органом, який інформує про це Комісію. Правозастосування здійснюється відповідно до чинного законодавства України. Умови правозастосування повинні бути визначені у відповідних грантових договорах чи контрактах. Законність рішення Європейської Комісії уповноважений розглядати Суд ЄС. Окрім того суди України уповноваженні розглядати скарги про неналежне здійснення правозастосування.

Для огляду та оцінювання реалізації цієї угоди спеціально створено Спільний комітет України та ЄС $з$ досліджень та інновацій. Крім того, до функцій комітету належать пошук шляхів удосконалення напрямів розвитку співробітництва, а також вирішення будь-яких питань, пов'язаних з тлумаченням або застосуванням угоди.

Асоційований статус у Рамковій програмі СС 3 досліджень та інновацій «Горизонт 2020» став важливим етапом у розвитку правових засад співпраці України з СС у космічній сфері, розширив можливості приєднання України до європейського наукового товариства, інтеграції в європейський дослідницький простір. Щоб максимально використати ці можливості, наша держава повинна чітко окреслити свої інтереси 3 урахуванням стратегічних пріоритетів. Назріла потреба створення відповідного органу 3 питань реалізації державної політики у сферах, охоплених програмою «Горизонт 2020». Україна висловила бажання скористатися своєю участю в програмі допомоги країнам, які хочуть оцінити свою систему наукових досліджень та інновацій у межах «Горизонт 2020». Свропейська Комісія підтвердила заявку та розпочала у 2016 р. аудит. Зокрема, оцінювання здійснюватиметься за такими напрямами, що визначені Україною: інституційний та операційний напрями щодо проведення в нашій країні конкурсів із фінансування наукових досліджень; інтернаціоналізація науки та входження України до європейського дослідницького простору та взаємозв'язок науки та інновацій [Актуальні питання, 2016].

Пріоритетні напрями космічної діяльності визначені у Концепції загальнодержавної цільової науково-технічної космічної програми, схваленій Кабінетом Міністрів України від 15 лютого 2012 р. [Про схвалення, 2012], співпадають $з$ пріоритетами Рамкової програми «Горизонт 2020», в яких космічні дослідження визначені пріоритетними для фінансування. Зокрема, вони також включають такі напрями, як глобальні навігаційні супутникові системи; спостереження Землі та глобальний моніторинг; космічна наука та дослідження; прикладні космічні технології, зокрема пускові технології та технології ракетних двигунів.

У космічній програмі України, супутниковій навігаційній тематиці відведено значну роль, оскільки в останні роки цей напрям стрімко розвивається. Законодавчо ця діяльність була закріплена законами України про затвердження другої (1998-2002), третьої (2003-2007), четвертої (2008-2012), п’ятої (2013-2017) та шостої (2018-2022) загальнодержавних космічних програм України, в яких передбачено, що одним із стратегічних напрямів розвитку держави у космічній сфері є виконання заходів зі створення та розвитку системи координатно-часового та навігаційного забезпечення. Навігаційна система України грунтується, зокрема, на застосуванні глобальної навігаційної системи «Галілео», яка сьогодні створюється спільними зусиллями ЄС та ЄКА.

Відповідно до регламенту Ради ЄС № 1285/2013 щодо реалізації та використання європейських супутниково-навігаційних систем від 11 грудня 2013 р., програма «Галілео» відкрита для участі третіх країн [Регламент, 2013]. Україна вже співпрацює з СС в межах 
реалізації першої європейської космічної програми з побудови європейської глобальної системи супутникової навігації «Галілео». Основу для співробітництва закладено Угодою про співробітництво щодо цивільної глобальної навігаційної супутникової системи (ГНСС) між Україною та ЄС і його державами - членами від 7 червня 2005 p. Україна офіційно приєдналася до європейської системи «Галілео» шляхом ратифікації Верховною Радою України угоди 10 січня 2007 р., що набула чинності з 1 грудня 2013 $\mathrm{p}$ [Угода, 2007].

Угода, що складається 317 статей, має рамковий характер та встановлює лише предметну співпрацю України та ЄС щодо використання зацікавленими суб'єктами господарської діяльності економічних можливостей європейського ринку супутникової навігації. Зокрема, сферами співробітництва визначено спектр радіочастот, наукові дослідження та підготовку персоналу; промислове співробітництво; розвиток торгівлі та ринку; стандарти, сертифікацію та регулятивні заходи; розвиток глобальних і регіональних наземних аугментаційних систем ГНСС; безпеку; відповідальність та відшкодування витрат.

Окрім того, передбачено можливість розширення співробітництва шляхом укладання додаткових спеціальних угод. Як об'єкти окремих угод розглядаються питання розширення співробітництва у сферах чутливих технологій та елементів системи «Галілео», а також основних технологій і засобів шифрування і питань захисту інформації; архітектури безпеки системи «Галілео»; особливостей контролю безпеки глобальних сегментів «Галілео»; послуг, що регулюються державою, на фазах їх визначення, розробки, впровадження, перевірки та оцінювання, а також функціонування; обміну інформацією з обмеженим доступом стосовно супутникової навігації.

Першорядні заходи співпраці в межах цієї угоди спрямовані на визначення $\mathrm{i}$ реалізацію архітектури наземної системи, яка надає оптимальну гарантію цілісності та безперервності послуг «Галілео» $\mathrm{i}$ «Егнос» та сумісності з іншими ГНСС. 3 цією метою на регіональному рівні сторони співпрацюють з намірами реалізації наземної регіональної аугментаційної системи в Україні на базі системи «Галілео». Така регіональна система покликана забезпечити надання регіональних послуг щодо цілісності й підвищення точності як доповнення до тих, які забезпечує система «Галілео» на глобальному рівні. Попередньо сторони передбачають поширення «Егнос» на регіон України через наземну інфраструктуру з використанням українських станцій моніторингу цілісності.

Для організаційного забезпечення виконання Угоди передбачається створення управлінського комітету ГНСС, що складатиметься із офіційних представників кожної сторони. Окресливши політичні та правові межі потенційної співпраці, угода надасть змогу Україні не лише взяти участь у реалізації першої європейської космічної програми $€ \mathrm{C}$, зберегти та розвинути свої високотехнологічні галузі та створити в них робочі місця, а й долучитися до інших програм ЄС. Зокрема, українські компанії можуть взяти участь у програмах комерційного використання системи в інтересах усіх видів транспорту, паливно-енергетичного і аграрно-промислового комплексів, досліджень i захисту навколишнього природного середовища; створити спільні підприємства 3 європейськими партнерами для виробництва складових наземних і космічних елементів системи «Галілео» [Угода, 2007].

Про перспективу реалізації цього напряму взаємовигідного співробітництва між $\mathrm{CC}$ та Україною свідчить підписання 27 листопада 2013 р. в Брюсселі на рівні керівництва Уряду України та Європейської Комісії Спільної заяви щодо започаткування проекту 
поширення дії системи «Егнос» на територію України, а саме про здійснення практичних кроків щодо розміщення станцій моніторингу діапазону та інтегрованості сигналу системи «Егнос» [Наука і технології, 2018].

Водночас, успішної реалізації цього взаємовигідного напряму співробітництва між Україною та СС, використання можливостей, які надає нашій державі ця угода, необхідно вжити низку інституційних і законодавчих заходів. По-перше, розробити чіткий план заходів з імплементації угоди та створити спеціальну спільну робочу групу для узгодження подальших спільних дій. По-друге, створити нормативно-правову базу для забезпечення стабільної, безпечної та сталої основи розвитку ГНСС в Україні, завершивши роботу із розробки спеціального закону, який би регулював діяльність ГHCC.

На законодавчому рівні залишаються неврегульованими питання провадження діяльності у сфері супутникової навігації, зокрема такі: організація державних закупівель i використання засобів супутникової навігації; державна підтримка вітчизняного виробництва супутникової навігаційної апаратури; відповідальність виробників супутникової навігаційної апаратури та суб'єктів господарювання, які надають навігаційні та інформаційні послуги; забезпечення безпечного використання інформації глобальних навігаційних супутникових систем; упровадження сучасних супутникових навігаційних технологій; розроблення та застосування національних стандартів і технічних регламентів щодо виробництва апаратури та засобів супутникової навігації, надання навігаційних інформаційних послуг [Про схвалення, 2013].

Щоб заповнити цю прогалину, треба виконати такі першорядні завдання: визначити на законодавчому рівні напрями діяльності із забезпечення розвитку та застосування систем супутникової навігації; встановити вимоги до провадження підприємницької діяльності у сфері супутникової навігації; надати підтримку вітчизняному виробнику супутникової навігаційної апаратури; запровадження державного регулювання у сфері супутникової навігації; визначити механізм державно-приватного партнерства у сфері супутникової навігації для забезпечення розвитку вітчизняного виробництва. В Україні наразі немає спеціального закону, який би регулював експлуатацію ГНСС та сфери ї застосування, але робота з його створення вже розпочалася. Зокрема, ДКАУ на виконання пункту другого розпорядження Кабінету Міністрів України від 03.01.2013 №1-р «Про схвалення Концепції проекту Закону України «Про державне регулювання у сфері супутникової навігації»»» розроблено проект закону «Про державне регулювання у сфері супутникової навігації» з урахуванням зауважень і пропозицій, наданих центральними органами виконавчої влади, НАН України, підприємствами промисловості, фізичними особами [Державне, 2018]. У проекті визначено права суб'єктів супутникової навігаційної діяльності, запропоновано заходи державного регулювання, спрямовані на вирішення проблем розвитку вітчизняного виробництва і внутрішнього ринку прикладних супутникових навігаційних інформаційних систем і послуг, окреслено вимоги та умови провадження підприємницької діяльності в сфері супутникової навігації в Україні.

Водночас у висновку Національної комісії, що здійснює державне регулювання у сфері зв'язку та інформатизації щодо проекту закону України «Про державне регулювання у сфері супутникової навігації» від 08. 02. 2016 р. відзначено необхідність суттєвого доопрацювання цього документа та надано пропозиції [Висновок, 2017].

По-третє, для використання можливостей, які надає Україні угода, потрібно також вирішити питання участі України в Європейському агентстві з питань глобальної 
навігаційної супутникової системи створеного на підставі регламенту Ради ЄС № 912/2010 від 22 вересня 2010 р. [Regulation, 2010]. Участь України у цьому агентстві $\epsilon$ можливою відповідно до ст. 23 регламенту про його створення, згідно 3 яким агентство залишається відкритим для участі третіх країн, які уклали відповідні угоди з ЄС. Предметом окремих двосторонніх угод агентства 3 третьою країною є питання визначення умов, ступеня та способу участі відповідної країни в роботі агентства, включаючи положення про розмір і порядок фінансових внесків та кадрові питання.

Повноцінна участь України в агентстві дасть можливість делегувати свого представника до правління та дорадчих органів, отримувати оперативну інформацію про перебіг реалізації європейської глобальної системи супутникової навігації «Галілео», брати участь у всіх заходах агентства, укладати контракти з приватними фірмами держав членів СС щодо запровадження та управління фазами розгортання та функціонування програми. Фінансовий аспект участі України у Свропейському агентстві з питань ГНСС не варто розцінювати як витрати, а як інвестиції, що повернуться українським підприємствам і науковим установам у формі контрактів.

Отже, на підставі проведеного аналізу правових засад співробітництва України та ЄC у космічній сфері можна зробити наступні висновки. Документом, який визначає головні напрями та пріоритети співпраці України з СС у космічній сфері, є Угода про асоціацію. Однак ії̈ положення стосовно зазначеної сфери є дещо загальними і потребують конкретизації у подальших двосторонніх документах між Україною та СС. Зокрема, першим кроком на цьому шляху стало підписання Угоди між Україною та СС про асоційовану участь України в програмі СС «Горизонт 2020» 2015 р., яка запроваджує спеціальний правовий механізм участі України у програмах ЄС. Один з небагатьох на сьогодні конкретних напрямів співпраці між Україною та СС визначений Угодою про співробітництво щодо цивільної глобальної навігаційної супутникової системи (ГНСС) між Україною та ЄС та його державами-членами 2013 р. Для використання можливостей, які надає Україні ця угода, насамперед необхідно створити нормативно-правову базу для стабільного, безпечного та сталого розвитку ГНСС в Україні, що має важливе значення для вирішення навігаційних завдань наземного, морського й авіаційного транспорту за допомогою супутникового зв'язку, у цьому контексті, першочергово необхідно завершити роботу щодо прийняття спеціального закону, який би регулював діяльність ГНСС. Серед пріоритетів подальшого співробітництва України з СС - набуття нашою державою членства в Свропейському космічному агентстві. Важливим кроком у цьому напрямі має стати укладення європейської коопераційної угоди з СКА. Цей документ, який $\epsilon$ формою поглибленої співпраці агентства з європейськими державами — не членами СКА, дасть змогу конкретизувати співпрацю на партнерських засадах і брати участь у програмах агентства; уможливить застосування спеціального фінансового механізму під назвою «принцип справедливого географічного повернення», який сприятиме розвитку національної космічної промисловості України; надасть право використовувати космічну інфраструктуру та активи агентства і його держав-членів при плануванні та реалізації своїх космічних проектів. Окрім того, підписання та виконання цієї угоди $€$ необхідною правовою умовою набуття повноправного членства в СКА. 


\section{Література}

Актуальні питання реалізації участі України у програмі «Горизонт 2020». 2016. http:// innov.org.ua/cpivpratsia/prohramy-spivpratsi/3959-aktualni-pytannia-realizatsiiuchasti-ukrainy-u-prohrami-horyzont-2020

Висновок Національної комісії, щзо здійснює державне регулювання у сфері зв'язку та інформатизації щодо проекту Закону України «Про державне регулювання у сфері супутникової навігаціï» від 17.01.2017 № 26 URL: http://www.nkrzi.gov.ua/ images/upload/493/6713/Dodatok_do_rishennia_26.doc

Державне космічне агентство Украӥни. 20-18. http://www.nkau.gov.ua/ua/

Конвениія про заснування СКА. Космическое законодательство стран мира: тематическое собрание (на русском и английском языках). Т. 2. Киев: Атика-Н, 2002. C. 141-176.

Международное сотрудничество в области использования космического пространства 6 мирных иелях: деятельность государств-членов. Док. ООН (А/АС.105/953/ Add.2). Вена, 2010. 21 с.

Наука і технологї, співробітництво у сфері космосу. 2018. http://ukraine-eu.mfa.gov.ua/ ua/ukraine-eu/sectoral-dialogue/science

Про ратифікаиію Угоди між Україною і Свропейським Союзом про участь Украӥни у програмі Свропейського Союзу Горизонт 2020 - Рамкова програма з досліджень та інновацій (2014-2020): Пояснювальна записка до проекту Закону України від 20.03.2015 p. http://w1.c1.rada.gov.ua/pls/zweb2/webproc34?id=\&pf3511=55776\& pf35401 $=349636$

Про схвалення Концепиії Загальнодержавної изільової науково-технічної космічної програми на 2013-2017 роки. Прийняття від 15.02.2012. https://zakon1.rada.gov.ua/ laws/show/79-2012-\%D1\%80

Про схвалення Концепиії проекту Закону Украӥни “Про державне регулювання у сфеpi супутникової навігаиї”. Прийняття від 03.01.2013. https://zakon4.rada.gov.ua/ laws/show/1-2013-\%D1\%80

Протокол до Угоди про партнерство і співробітництво між Украӥною $і$ Європейськими Співтовариствами та їх державами-членами про Рамкову угоду між Украӥною та Свропейським Співтовариством про загальні принципи участі України в програмах Співтовариства. Набрання чинності для України міжнародного договору від 01.11.2011. https://zakon.rada.gov.ua/laws/show/994_a41

Протокол про внесення змін до Угоди між Урядом України та авропейським космічним агентством щзодо співробітництва у використанні космічного простору в мирних иілях. 14.02.2014 p. http://zakon4.rada.gov.ua/laws/show/982_002

Регламент Свропейського Парламенту та Ради про створення Горизонту 2020 - Рамкової програми 3 досліджень та інновацій (2014-2020). Official Journal of the European Union. 2013. L 347.

Регламент Ради (СС, Свратом) № 2988/95 від 18 грудня 1995 року про захист фінансових інтересів Свропейських Співтовариств. Official Journal of the European Union. 1995. L 312. P. 1-4.

Угода про співробітництво щзодо циивільної глобальної навігаційної супутникової системи (ГНСС) між Свропейським Співтовариством, державами-членами та Україною. Ратифікація від 10.01.2007. http://zakon2.rada.gov.ua/laws/show/994_751 
Угода між урядом України та Європейським космічним агентством щзодо співробітництва у використанні космічного простору у мирних изілях. 30.10.2008 p. URL: http://zakon4.rada.gov.ua/laws/show/982_001

Угода про асоиіачію між Украӥною, з однієї сторони, та Свропейським Союзом і його державами-членами, з іншої сторони. 16.09.2014 p. URL: http://zakon2.rada.gov. ua/laws/show/984_011

Угода між Украӥною і Свропейським Союзом про участь Украӥни у програмі Свропейського Союзу Горизонт 2020 - Рамкова програма з досліджень та інновацій (2014-2020).15.07.2015 p. http://zakon2.rada.gov.ua/laws/show/984_018

Чернишев, Л., Білан, І., Гороховатська, М. Назустріч новій Рамковій програмі європейського науково-технічного співробітництва «Горизонт-2020». Вісник Національної академії наук України. 11, 2012: 47-52.

Contracting for Space: Contract Practice in the European Space Sector. Edited by Lesley Jane Smith and Ingo Baumann. Routledge, 2011.

Commission White paper. Space: a new European frontier for an expanding Union - An action plan for implementing the European Space policy 2003. URL: http://eur-lex. europa.eu/legal-content/en/TXT/?uri=CELEX:52003DC0673

European Cooperating State agreement between the European space agency and the Government of the Republic of Slovenia. 1975. http:/www.arhiv.mvzt.gov.si/fileadmin/ mvzt.gov.si/pageuploads/doc/razpisi/razpisi_tehnologija/javni_poziv_ESA/European_ Cooperating_State_Agreement_between_the_RS_and_the_ESA.pdf

European Space Policy Institute, 2018. https://espi.or.at/

Poncelet, J-P., Anabelle F-C., Giulio G. Enlarging ESA? - After the Accession of Luxembourg and Greece. ESA Bulletin. No. 120, 2004: 49-53.

Regulation (EU) of the European Parliament and of the Council No. 912/2010 of 22 September 2010 setting up the European GNSS Agency. Official Journal of the European Union. 2010. L 276. P. 11-21.

Treaty of Lisbon amending the Treaty on European Union and the Treaty establishing the European Community, signed at Lisbon, 13 December 2007.

\section{References}

Aktualni pytannia realizatsii uchasti Ukrainy u prohrami «Horyzont 2020». 2016. http://innov. org.ua/cpivpratsia/prohramy-spivpratsi/3959-aktualni-pytannia-realizatsii-uchastiukrainy-u-prohrami-horyzont-2020

Vysnovok Natsionalnoi komisii, shcho zdiisniuie derzhavne rehuliuvannia u sferi zviazku ta informatyzatsii shchodo proektu Zakonu Ukrainy «Pro derzhavne rehuliuvannia u sferi suputnykovoi navihatsii» vid 17.01.2017 № 26 URL: http://www.nkrzi.gov.ua/images/ upload/493/6713/Dodatok_do_rishennia_26.doc

Derzhavne kosmichne ahentstvo Ukrainy. 2018. http:/www.nkau.gov.ua/ua/

Konventsiia pro zasnuvannia YeKA. Kosmycheskoe zakonodatelstvo stran myra: tematycheskoe sobranye (na russkom y anhlyiskom yazыkakh). T. 2. Kyev: Atyka-N, 2002. S. 141-176.

Mezhdunarodnoe sotrudnychestvo v oblasty yspolzovanyia kosmycheskoho prostranstva v myrnыkh tseliakh: deiatelnost hosudarstv-chlenov. Dok. OON (A/AC.105/953/Add.2). Vena, 2010.21 s. 
Nauka i tekhnolohii, cpivrobitnytstvo u sferi kosmosu. 2018. http:/ukraine-eu.mfa.gov.ua/ua/ ukraine-eu/sectoral-dialogue/science

Pro ratyfikatsiiu Uhody mizh Ukrainoiu i Yevropeiskym Soiuzom pro uchast Ukrainy u prohrami Yevropeiskoho Soiuzu Horyzont 2020 - Ramkova prohrama z doslidzhen ta innovatsii (2014-2020): Poiasniuvalna zapyska do proektu Zakonu Ukrainy vid 20.03.2015 r. http:// w1.c1.rada.gov.ua/pls/zweb2/webproc34?id=\&pf3511=55776\&pf35401=349636

Pro skhvalennia Kontseptsii Zahalnoderzhavnoi tsilovoi naukovo-tekhnichnoi kosmichnoi prohramy na 2013-2017 roky. Pryiniattia vid 15.02.2012. https://zakon1.rada.gov.ua/ laws/show/79-2012-\%D1\%80

Pro skhvalennia Kontseptsii proektu Zakonu Ukrainy "Pro derzhavne rehuliuvannia u sferi suputnykovoi navihatsii”. Pryiniattia vid 03.01.2013. https://zakon4.rada.gov.ua/laws/ show/1-2013-\%D1\%80

Protokol do Uhody pro partnerstvo i spivrobitnytstvo mizh Ukrainoiu i Yevropeiskymy Spivtovarystvamy ta yikh derzhavamy-chlenamy pro Ramkovu uhodu mizh Ukrainoiu ta Yevropeiskym Spivtovarystvom pro zahalni pryntsypy uchasti Ukrainy v prohramakh Spivtovarystva. Nabrannia chynnosti dlia Ukrainy mizhnarodnoho dohovoru vid 01.11.2011. https://zakon.rada.gov.ua/laws/show/994_a41

Protokol pro vnesennia zmin do Uhody mizh Uriadom Ukrainy ta Yevropeiskym kosmichnym ahentstvom shchodo spivrobitnytstva u vykorystanni kosmichnoho prostoru v myrnykh tsiliakh. 14.02.2014 r. http://zakon4.rada.gov.ua/laws/show/982_002

Rehlament Yevropeiskoho Parlamentu ta Rady pro stvorennia Horyzontu 2020 - Ramkovoi prohramy z doslidzhen ta innovatsii (2014-2020). Official Journal of the European Union. 2013. L 347.

Rehlament Rady (IeS, Yevratom) № 2988/95 vid 18 hrudnia 1995 roku pro zakhyst finansovykh interesiv Yevropeiskykh Spivtovarystv. Official Journal of the European Union. 1995. L 312. R. 1-4.

Uhoda pro spivrobitnytstvo shchodo tsyvilnoi hlobalnoi navihatsiinoi suputnykovoi systemy (HNSS) mizh Yevropeiskym Spivtovarystvom, derzhavamy-chlenamy ta Ukrainoiu. Ratyfikatsiia vid 10.01.2007. http://zakon2.rada.gov.ua/laws/show/994_751

Uhoda mizh uriadom Ukrainy ta Yevropeiskym kosmichnym ahentstvom shchodo spivrobitnytstva u vykorystanni kosmichnoho prostoru u myrnykh tsiliakh. 30.10.2008 r. URL: http://zakon4.rada.gov.ua/laws/show/982_001

Uhoda pro asotsiatsiiu mizh Ukrainoiu, z odniiei storony, ta Yevropeiskym Soiuzom i yoho derzhavamy-chlenamy, z inshoi storony. 16.09.2014 r. URL: http://zakon2.rada.gov.ua/ laws/show/984_011

Uhoda mizh Ukrainoiu i Yevropeiskym Soiuzom pro uchast Ukrainy u prohrami Yevropeiskoho Soiuzu Horyzont 2020 — Ramkova prohrama z doslidzhen ta innovatsii (2014-2020). 15.07.2015 r. http://zakon2.rada.gov.ua/laws/show/984_018

Chernyshev, L., Bilan, I., Horokhovatska, M. Nazustrich novii Ramkovii prohrami yevropeiskoho naukovo-tekhnichnoho spivrobitnytstva «Horyzont-2020». Visnyk Natsionalnoi akademii nauk Ukrainy. 11, 2012: 47-52.

Contracting for Space: Contract Practice in the European Space Sector. Edited by Lesley Jane Smith and Ingo Baumann. Routledge, 2011.

Commission White paper. Space: a new European frontier for an expanding Union - An action plan for implementing the European Space policy 2003. URL: http://eur-lex. europa.eu/legal-content/en/TXT/?uri=CELEX:52003DC0673 
European Cooperating State agreement between the European space agency and the Government of the Republic of Slovenia. 1975. http://www.arhiv.mvzt.gov.si/fileadmin/ mvzt.gov.si/pageuploads/doc/razpisi/razpisi_tehnologija/javni_poziv_ESA/European_ Cooperating_State_Agreement between the RS and the ESA.pdf

European Space Policy Institute, 2018. https://espi.or.at/

Poncelet, J-P., Anabelle F-C., Giulio G. Enlarging ESA? — After the Accession of Luxembourg and Greece. ESA Bulletin. No. 120, 2004: 49-53.

Regulation (EU) of the European Parliament and of the Council No. 912/2010 of 22 September 2010 setting up the European GNSS Agency. Official Journal of the European Union. 2010. L 276. P. 11-21.

Treaty of Lisbon amending the Treaty on European Union and the Treaty establishing the European Community, signed at Lisbon, 13 December 2007. 